Thorax (1965), 20, 21.

\title{
Precipitin (F.L.H.) test in farmer's lung
}

\author{
J. PEPYS A N D P. A. JE N K I N S \\ From the M.R.C. Research Group in Clinical Immunology, Department of Medicine, Institute of \\ Diseases of the Chest, London, S.W.3
}

Farmer's lung may be defined as the disease resulting from the inhalation of the dust of mouldy hay and of other mouldy vegetable materials, with symptoms and signs attributable to a reaction in the most peripheral part of the bronchopulmonary tree. The presence, in patients suffering from farmer's lung, of precipitins against antigens in mouldy hay, reported by Pepys, Riddell, Citron, and Clayton (1961; 1962), has been confirmed by Kobayashi, Stahmann, Rankin, and Dickie (1963) and by Bishop, Melnick, and Raine (1963). Pepys, Jenkins, Festenstein, Gregory, Lacey, and Skinner (1963) have since found that the main sources of 'farmer's lung hay' (F.L.H.) antigens are thermophilic actinomycetes, the most important being Thermopolyspora polyspora, on which the present serological findings are based, and Micromonospora vulgaris (Thermoactinomyces vulgaris).

Earlier repoits of the disease suggested that a well-defined group of symptoms and signs was typical (Campbell, 1932; Studdert, 1953; Fuller, 1953; Dickie and Rankin, 1958). It is important, however, to decide whether less typical pulmonary manifestations in a farmer exposed to mouldy hay are pathogenetically similar and should be included in the category of farmer's lung. The main features of typical acute attacks are the appearance, some hours after exposure to the dust, of crepitations together with dyspnoea, cough, and perhaps haemoptysis, malaise, chills, fever, and loss of weight. The symptoms are often more striking than the physical signs. Radiography of the lungs may show a widely distributed miliary infiltration or ground-glass appearance, which resolves within weeks or months of the attack. Reactions in the larger bronchi are not a part of farmer's lung, and a history of previous allergic asthma or bronchitis is seldom present. The pulmonary reaction in farmer's lung takes place in the peripheral part of the bronchopulmonary tree, which may be infiltrated with epithelioid cell granulomata, and is accompanied by impaired diffusion of gas and decreased compliance of the lungs, with minimal ventilatory disturbance (Dickie and Rankin, 1958, 1960; Seal, Thomas, and Griffiths, 1963; Bishop and others, 1963; Williams, 1963a, b).
In their survey of farmer's lung in the United Kingdom, Staines and Forman (1961) added to the above criteria of farmer's lung the presence of wheezing, predominantly inspiratory, and they stated that mild cases might present 'rather like dustprovoked asthmatic bronchitis', and that moderate or severe cases might start similarly. This raises the problem of distinguishing in a farmer between asthma or bronchitis and farmer's lung. A similar problem is present in farmers found to have diffuse pulmonary fibrosis, since this is a not uncommon result of repeated attacks of farmer's lung but may also develop from other causes in a patient who happens to be a farmer.

In most reports on farmer's lung the condition is described as having started with typical acute attacks, but Staines and Forman (1961) report that an insidious onset occurred equally frequently.

The serological findings reported here will be examined in relation to subjects who were or were not farmworkers, to the different modes of onset of farmer's lung, and to the presence or absence of other pulmonary disease.

\section{MATERIALS AND METHODS}

TEST EXTRACTS Freeze-dried preparations of extracts of mouldy hays in Coca's solution and of the culture medium of the following actinomycetes and fungi were dissolved at $10 \mathrm{mg} . / \mathrm{ml}$. for double-diffusion and 30 $\mathrm{mg}$./ml. for immuno-electrophoretic tests (Pepys and others, 1963).

1. Extracts of specimens of the following mouldy hays were mainly used for testing: (a) mouldy hay $\mathrm{H} 44$, which was naturally occurring mouldy hay associated with a case of farmer's lung (Gregory and Lacey, 1963); (b) mouldy hays Hlb and L8, which were prepared in the laboratory from sterile hay, the moisture content of which had been raised to $40 \%$. This hay was inoculated with a mixed suspension of the microbial flora of $\mathrm{H} 44$ and was then incubated at $40^{\circ} \mathrm{C}$. for two and three weeks respectively (Pepys and others, 1963); (c) tests were also made with extracts of two experimental mouldy hays which were under investigation at Rothamsted Experimental Station by Dr. P. H. Gregory and his colleagues. Mouldy hay V4 was prepared by placing chopped hay, $u$ ith a moisture content of $40 \%$, into a well-lagged barrel. The hay underwent self-heating with a gradual rise of temperature to $56^{\circ} \mathrm{C}$, , and extracts were prepared after 
nine days. Mouldy hay V17 was prepared in a Thermos flask from chopped hay with a moisture content of $34 \%$. This hay behaved differently from V4, showing two rapidly developing and subsiding rises of temperature to $55^{\circ} \mathrm{C}$., and extracts were prepared from it after one week.

2. (a) $T$. polyspora and $M$. vulgaris were cultured on nutrient agar medium at $40^{\circ} \mathrm{C}$. for four days, and extracts were prepared from the liquid which was freed from the medium by alternate freezing and thawing. (b) Preparations of the antigenic fractions of the culture filtrate extract of $T$. polyspora were made by precipitation with trichloracetic acid. A solution of trichloracetic acid $40 \%$ was added drop by drop to a solution of $80 \mathrm{mg}$. $/ \mathrm{ml}$. of the freeze-dried $T$. polyspora extract to give a final concentration of $4 \%$. After standing overnight at $4^{\circ} \mathrm{C}$., the trichloracetic acid precipitate was separated by centrifugation, and this was freeze-dried after dialysis overnight against running tap-water to remove the trichloracetic acid.

The supernatant solution was also dialysed overnight and then concentrated twofold. Trichloracetic acid was added once again, and the precipitate was discarded. The final supernatant solution was freeze-dried after passage through a Sephadex G 25 column. Two fractions were obtained, one in the precipitated material and the other in the supernatant. Approximately one-tenth of the original freeze-dried material was present in the precipitate, the remainder being present in the supernatant.

3. Freeze-dried extracts were prepared from the culture media of a one-month culture at $37^{\circ} \mathrm{C}$. of a Mucor sp. on Sabouraud's glucose-peptone broth, and of a twoweek culture at $27^{\circ} \mathrm{C}$. of Aspergillus fumigatus IMI 48337 on Czapek-Dox medium.

IMMUNOLOGICAL TESTS Agar-gel double-diffusion and immuno-electrophoretic tests were made as described by Pepys and others (1963). The double-diffusion test was found to be more sensitive than the immunoelectrophoretic test. The latter test, however, was more discriminating, making it possible to identify specific reactions by their position in the agar-gel.

The immuno-electrophoretic test was made by a micro-method on glass slides $8 \mathrm{~cm}$. square, which enabled a number of tests to be performed on the one slide. The dimensions and placing of the antigen wells and serum trough were kept constant to ensure comparability of results (Fig. 1). The antigen wells were $2 \mathrm{~mm}$. in diameter and were placed midway between the serum troughs, which were $5 \mathrm{~cm}$. in length, $1 \mathrm{~mm}$. in diameter, and $1 \cdot 2 \mathrm{~cm}$. away from each other. The antigen wells were placed $1.5 \mathrm{~cm}$. away from the cathodal ends of the troughs. In order to show up fine or faint precipitation arcs the immuno-electrophoretic test slides were washed overnight in $0.9 \%$ saline plus $0.1 \%$ sodium azide. The film of agar was dried between sheets of Whatman 3 MM filter paper in an oven at about $40^{\circ} \mathrm{C}$. and then stained with $0.5 \%$ naphthalene black $10 \mathrm{~B}$ in a mixture of 5 parts methanol, 4 parts water, and 1 part glacial acetic acid.

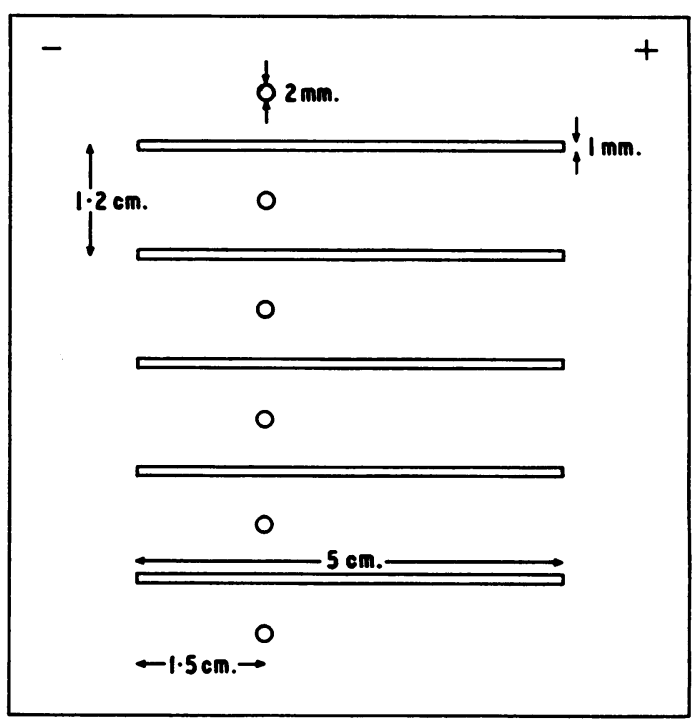

FIG. 1. Immuno-electrophoretic test pattern.

GRADING OF THE IMMUNO-ELECTROPHORETIC TEST REACTIONS The main specific precipitation arcs in tests with farmer's lung sera and extracts of mouldy hay have been described in three regions which have been labelled A, B, and C (Fig. 2). These arcs were due to antigens which are present in mouldy hay responsible for farmer's lung, and which were therefore termed 'farmer's lung hay' or F.L.H. antigens (Pepys and others, 1963). The precipitation reactions produced by these antigens in one or more of the three regions with their corresponding specific precipitins will be termed F.L.H. reactions. Since the antigens responsible for these arcs correspond with antigens present in extracts of $T$. polyspora, and since this organism is the only source of all three antigens so far isolated from mouldy hay, the arcs in the A, B, and $\mathrm{C}$ regions will be referred to as F.L.H. reactions ( $T$. polyspora type).

An arc in the $\mathrm{C}$ region due to an antigen in common with $T$. polyspora was produced by extracts of $M$. vulgaris. More than one arc was frequently seen in the $A$, $B$, and $C$ regions, and other arcs were found less frequently in contiguous regions; an example of the latter can be seen in the reaction produced by the antigens in the supernatant of the $T$. polyspora extract after trichloracetic acid precipitation (Fig. 3). The significance of these additional arcs has not been assessed. The possibility that there are other sources of antigen in mouldy hay of importance in farmer's lung and capable of giving reactions in regions other than the $\mathrm{A}, \mathrm{B}$, and $\mathrm{C}$ regions has to be considered. If these are found they could be added to the range of F.L.H. antigens, together with the name of the source for purposes of identification.

The precipitation arcs in regions $A, B$, and $C$ of the F.L.H. ( $T$. polyspora) type have been graded in order to assess the intensity of the reaction. The presence of 


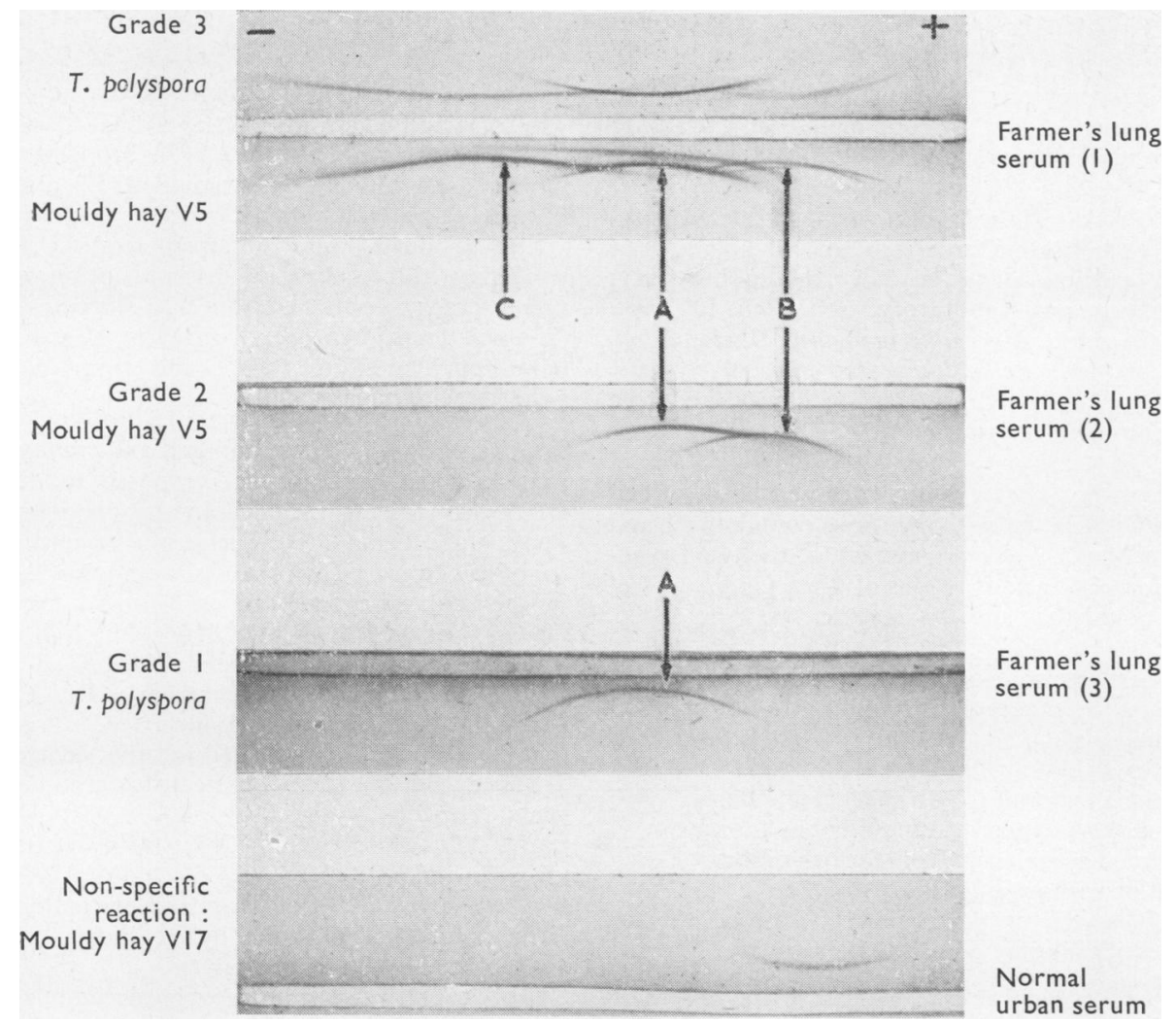

FIG. 2. Grades of F.L.H. reaction in immuno-electrophoretic test.

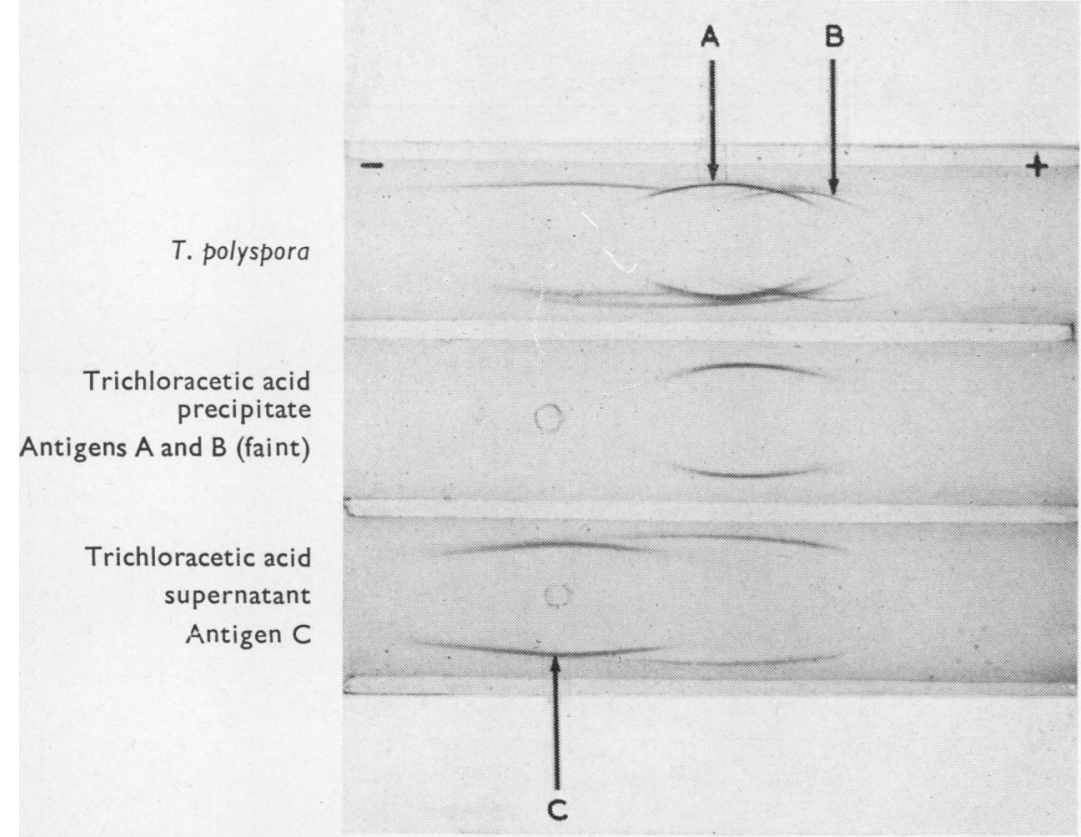

Farmer's lung serum

Farmer's lung serum

FIG. 3. T. polyspora trichloracetic acid fractions. 
arcs in all three regions has been termed grade 3 ; in two of the regions, grade 2 ; in one region only, grade 1 ; and negative reactions, grade 0 .

SKIN TESTS Prick tests were performed in selected subjects with carbol-saline solutions of $10 \mathrm{mg} . / \mathrm{ml}$. of freeze-dried extracts of good hay and mouldy hay, prepared in our own laboratory, and with $10 \% \mathrm{w} / \mathrm{v}$ extracts of Alternaria, Aspergillus fumigatus, Cladosporium herbarum, dry rot, Penicillium, Tricothecium, yeasts, Sporobolomyces, and of mixed grass, flower, and tree pollens (Duncan-Flockhart).

INHALATION TESTS These were performed as described by Williams $(1963 \mathrm{a}, \mathrm{b})$ with solutions containing 1 and $10 \mathrm{mg} . / \mathrm{ml}$. of the $T$. polyspora extract, of the two freezedried, trichloracetic acid fractions of $T$. polyspora, and of extracts of mouldy hay and $M$. vulgaris.

TEST SERA Test sera were obtained from the following :-

(1) subjects not engaged in farming and not exposed to mouldy hay

(a) urban dwellers who lived in London

(b) workers exposed to other vegetable dusts

(2) farm workers exposed to mouldy hay

(a) regarded as suffering from farmer's lung

(b) with or without other lung disease

(3) a small group of farm workers exposed to and affected by other mouldy cereal dusts.

(1) Subjects not engaged in farming The group of sera of urban dwellers who were not exposed to mouldy hay includes sera tested in the previous study of Pepys and others (1962) on which further tests have now been made. The total numbers were :-(1a) normal blood bank sera (60), patients with asthma (115), bronchitis (34), pulmonary aspergillosis (30), sarcoidosis (52), and interstitial fibrosis $(22)$; $(1 b)$ sera of workers exposed to other vegetable dusts were obtained from U.K. dockers working with cereal grains (61) and cotton workers (20). Other sera were obtained from East African sisal workers (20), and tea workers (20); from West African workers on palm-nut plantations (46); and from West Indians working with bagasse (52).

(2) Farmer's sera Three hundred and twenty-seven sera were obtained from farmers exposed to mouldy hay. Of these, 16 were included in the previous report by Pepys and others (1963). The sera of 16 farmers exposed to other mouldy cereal dusts were also tested. Most of the sera were provided as follows:-Wales: Drs. G. O. Thomas (86), R. W. Biagi (29), J. T. Jones (20), S. T. H. Jenkins (14) ; Ulster : Drs. C. T. B. Adams 145), E. F. James (37) ; Lancaster : Dr. J. L. Russell (17) ; Devon : Dr. C. J. Fuller (16). Groups of less than 10 sera were obtained from other centres.

The age distribution of the total group was: 10-19 years, $3 \%$; 20-29 years, $10 \%$; 30-39 ycars, $16 \% ; 40-49$ years, $23 \%$; 50-59 years, $31 \%$; 60-69 years, $15 \% ; 70$ years or more, $2 \%$.

A group of 12 sera from Icelandic patients with farmer's lung was provided by Dr. Bjornsson. These are not included in the main analysis.

(a) A total of 205 farmers were placed in the farmer's lung group. Information was sought on the clinical features listed in Table I. No questions were asked about

TABLE I

MODE OF ONSET OF CLINICAL FEATURES IN FARMER'S LUNG PATIENTS

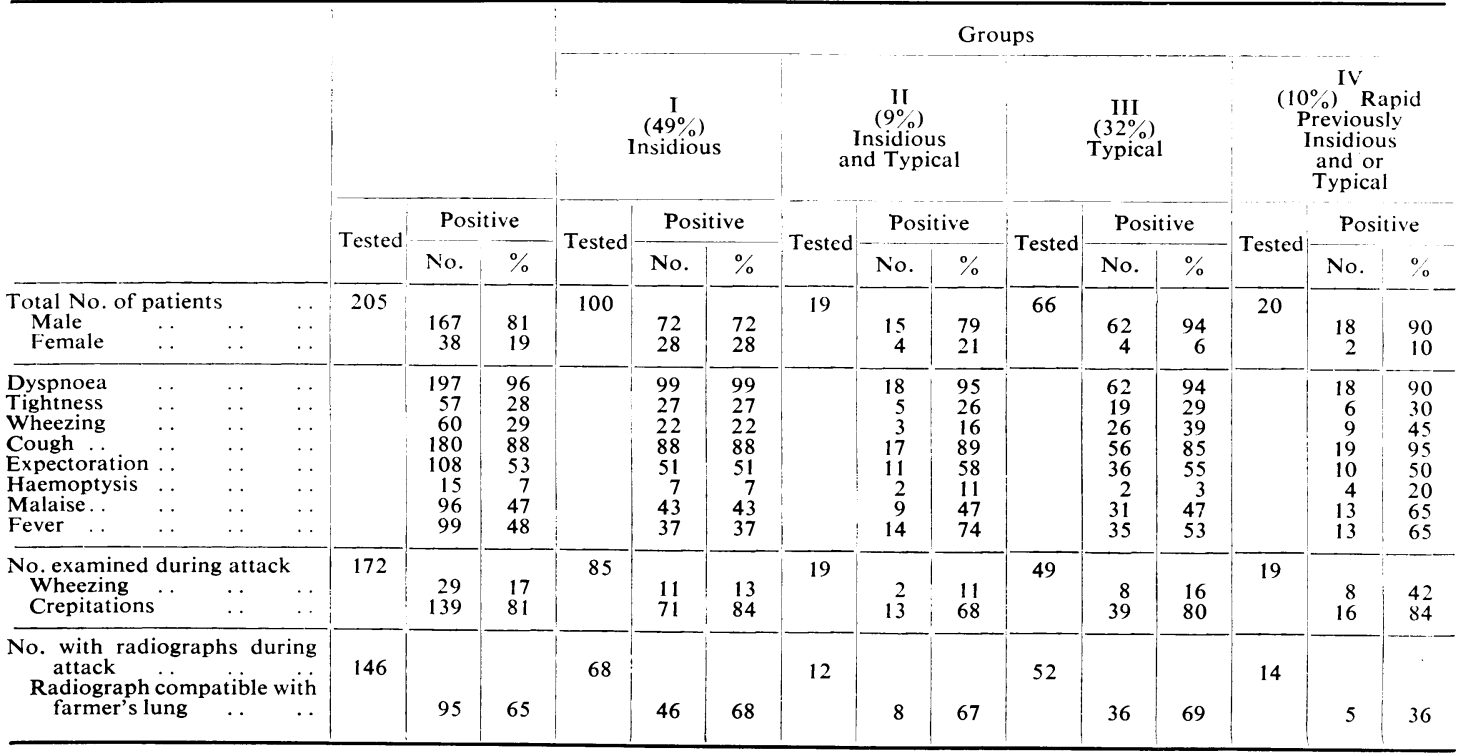


loss of weight, the clinicians spontaneously offering information in a small proportion of cases. Information on the presence or absence of wheezes or crepitations was available in $172(84 \%)$ of the patients who were examined during the attacks of farmer's lung, and radiographs taken during the illness were available for $146(71 \%)$ of the patients. Patients who had had asthma, bronchitis, and other pulmonary disease before exposure to the mouldy hay were excluded from this group unless, as in the 20 patients listed in Table II, there were additional features suggestive of farmer's lung in relation to the illness under observation. The last attack had occurred in $1963(45 \%) ; 1962(26 \%) ; 1961(9 \%) ; 1960$ $(5 \%)$; and $1959(10 \%)$. The remainder had their attacks from 1945 onwards, but very few had ceased being exposed to mouldy hay. The majority of the sera were examined during or shortly after the attacks, only about $10 \%$ being provided for examination two to three years or more after the last attack.

TABLE II

FEATURES SUGGESTIVE OF FARMER'S LUNG IN PATIENTS WITH PREVIOUS LUNG DISEASE

\begin{tabular}{l|c|c|c|c|c|c}
\hline $\begin{array}{c}\text { Previous } \\
\text { Disorder }\end{array}$ & $\begin{array}{c}\text { No. } \\
\text { of } \\
\text { Patients }\end{array}$ & $\begin{array}{c}\text { Crepi- } \\
\text { tations }\end{array}$ & Malaise & Fever & $\begin{array}{c}\text { Loss } \\
\text { of } \\
\text { Weight }\end{array}$ & $\begin{array}{c}\text { Com- } \\
\text { patible } \\
\text { Chest } \\
\text { Radio- } \\
\text { graph }\end{array}$ \\
\hline $\begin{array}{c}\text { Asthma . } \\
\text { Bronchitis . }\end{array}$ & 4 & 4 & 4 & 4 & 1 & 1 \\
$\begin{array}{l}\text { Pneumonia } \\
\text { Undiagnosed } \\
\text { disease .. }\end{array}$ & 4 & 4 & 3 & 3 & 2 & 2 \\
$\begin{array}{c}\text { Old } \\
\text { tuberculosis }\end{array}$ & 2 & 3 & 2 & 1 & & 2 \\
$\begin{array}{c}\text { Silicosis } \\
\text {.. }\end{array}$ & 1 & 2 & 1 & 1 & & 1 \\
\hline
\end{tabular}

The original descriptions of farmer's lung clearly dealt with the most striking cases, and it is these descriptions which have been followed in most of the subsequent reports. Unless it is recognized that this illness may have different modes of onset, the diagnosis is likely to be missed in many patients. The patients have been divided into four groups according to the mode of onset of the disorder (Table I). Group I, consisting of 100 patients $(49 \%)$, had an insidious onset and gave a history of constant or very frequent handling of mouldy hay for weeks and sometimes months before pulmonary symptoms became severe enough for medical advice to be sought. Group II, consisting of 19 patients ( $9 \%$, had an insidious onset to start with, followed later by typical acute attacks. Group III, consisting of 66 subjects $(32 \%)$, gave a history of typical attacks from the beginning. In this group the usual interval between exposure and symptoms was five to six hours or more, but not infrequently fever, aches and pains, a feeling of depression, and general debility developed within one to two hours of the exposure. Group IV, consisting of 20 patients $(10 \%)$, gave a history of insidious onset and subsequent typical attacks, and finally very rapid and sometimes immediate respiratory symptoms developed on exposure to the dust.
TABLE III

AGE DISTRIBUTION (\%) OF FARMER'S LUNG PATIENTS

\begin{tabular}{|c|c|c|c|c|}
\hline \multirow[b]{2}{*}{ Age (yr.) } & \multicolumn{4}{|c|}{ Group } \\
\hline & $\begin{array}{c}\text { I } \\
\text { Insidious }\end{array}$ & $\begin{array}{c}\text { II } \\
\text { Insidious } \\
\text { and Typical }\end{array}$ & $\underset{\text { Typical }}{\text { III }}$ & $\begin{array}{c}\text { IV } \\
\text { Rapid } \\
\text { Previously } \\
\text { Insidious } \\
\text { and or } \\
\text { Typical }\end{array}$ \\
\hline $\begin{array}{l}10-19 \\
20-29 \\
30-39 \\
40-49 \\
50-59 \\
60-69 \\
70\end{array}$ & $\begin{array}{r}2 \\
12 \\
19 \\
21 \\
34 \\
11 \\
1\end{array}$ & $\begin{array}{r}11 \\
26 \\
21 \\
37 \\
5\end{array}$ & $\begin{array}{r}2 \\
9 \\
17 \\
27 \\
26 \\
18 \\
1\end{array}$ & $\begin{array}{r}5 \\
15 \\
5 \\
45 \\
30\end{array}$ \\
\hline
\end{tabular}

The clinical features of the four groups of patients have been compared. Table III shows that group IV subjects (rapid onset) were slightly younger than those in the other groups. Table I shows that there were only small differences in the proportions of the patients in the groups complaining of dyspnoea, tightness of the chest, cough, expectoration of small amounts of sputum, haemoptysis, and malaise, and that there were also similar proportions with crepitations. Differences between the groups were as follows: group I (insidious onset) had the lowest proportion of patients with febrile episodes; group III (typical onset) had the highest proportion of males, suggesting that they were more heavily exposed and therefore more likely to get the typical acute attacks; and group IV (rapid onset) had the highest proportion of patients complaining of wheezing and with wheezes present, and the lowest proportion with radiographic evidence compatible with the disease, perhaps because the rapid onset of symptoms may have reduced the length of exposure and the amount of dust inhaled. Loss of weight was notified for $18 \%$ of the patients in group I, $37 \%$ in group II, $11 \%$ in group III, and $20 \%$ in group IV. It can be seen that the patients in group IV, in spite of the rapid onset of the symptoms, had malaise, fever, and crepitations with comparable frequency to the other groups, and loss of weight was also commented on as frequently.

In order to investigate the rapid bronchial reactions in group IV, skin 'prick' tests were made in 11 subjects. Only two gave positive immediate type reactions, one to an extract of good hay and the other to an extract of mouldy hay. Both patients had a history of previous allergic asthma. The negative reactions in the remainder suggest that some other mechanism is responsible for the bronchial reaction than the immediate type hypersensitivity which mediates asthma in atopic subjects.

(b) A group of 122 sera was obtained from farmers exposed to mouldy hay but not regarded as having farmer's luns. These included normal farmers in Wales and Ulster (28), who worked together with patients suffering from farmer's lung; and farmers with asthma with or without bronchitis (38), with bronchitis, with or without asthma (23), with interstitial fibrosis (15), in two of whom sarcoidosis was suspected, with sarcoidosis (9), with cardiac disease (2), with tuberculosis (1), and with undiagnosed pulmonary disease (6). 


\section{SEROLOGICAL RESULTS}

(1) SUBJECTS NOT ENGAGED IN FARMING Table IV shows that in tests with extracts of mouldy hay, both by double-diffusion and by immuno-electrophoresis, against some of the sera of group $1 a$, that is 134 urban sera, six reacted in the double-diffusion test, but neither these nor the remaining 128 sera gave any reactions in the immuno-electrophoretic test. In the previous study by Pepys and others (1962), 51 out of 170 urban sera gave positive reactions in the double-diffusion test to extracts of mouldy hay. Immuno-electrophoretic tests were made on these 51 sera, which consisted of 16 out of 50 sarcoidosis sera, 11 out of 90 asthmatic sera, and 24 out of 30 aspergillosis sera. None of these sera gave F.L.H. reactions in the immuno-electrophoretic test. In tests with extracts of mouldy hay

\section{TABLE IV}

REACTIONS TO MOULDY HAY EXTRACTS (H44, HIb, L8) OF SERA FROM NON-FARMING POPULATION

\begin{tabular}{|c|c|c|c|}
\hline $\begin{array}{l}\text { Clinical } \\
\text { Condition }\end{array}$ & $\begin{array}{c}\text { No. } \\
\text { of } \\
\text { Patients }\end{array}$ & $\begin{array}{c}\text { Double- } \\
\text { Diffusion } \\
\text { Test }\end{array}$ & $\begin{array}{l}\text { Immuno- } \\
\text { electro- } \\
\text { phoretic } \\
\text { Test }\end{array}$ \\
\hline 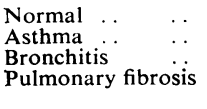 & $\begin{array}{l}60 \\
25 \\
34 \\
15\end{array}$ & $\begin{array}{l}3 \\
1 \\
1 \\
1\end{array}$ & $\begin{array}{l}0 \\
0 \\
0 \\
0\end{array}$ \\
\hline
\end{tabular}

against some of the sera of group $1 b$, that is 61 dockers working with cereal grains, three gave positive reactions in the double-diffusion test. These sera were not tested by immuno-electrophoresis. Like the other sera tested above, the proportion of reactions to extracts of mouldy hay was low.

Double-diffusion tests were made with extracts of $T$. polyspora (Table V), and immuno-electrophoretic
TABLE V

REACTIONS TO T. POLYSPORA EXTRACT OF CONTROL SERA OF NON-FARMING POPULATION AND SUBJECTS EXPOSED TO OTHER VEGETABLE DUSTS

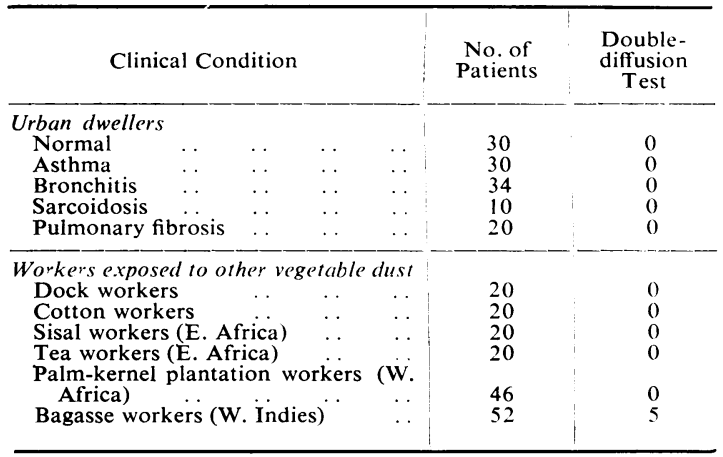

tests were made on those who gave positive reactions. No reactions were obtained with sera from group $1 a$, the 124 urban dwellers in the United Kingdom, or from group $1 b$, the 20 dockers exposed to cereal dusts and 20 cotton workers. No reactions were obtained with the sera of 20 E. African workers exposed to sisal and of 20 exposed to tea dusts, nor with the sera of $46 \mathrm{~W}$. African workers on a palmnut plantation. Of the $52 \mathrm{~W}$. Indian workers exposed to bagasse, five gave positive reactions on double-diffusion but none gave reactions when tested further by immuno-electrophoresis. In tests with the extract of $T$. polyspora on 302 sera from subjects not engaged in farming, five positive reactions were obtained in bagasse workers in the double-diffusion test only. These findings confirm the absence of antibodies capable of reacting with F.L.H. antigens, shown in the test with the mouldy hay extracts in subjects not exposed to mouldy hay.

TABLE VI

PRECIPITIN REACTIONS IN THE FOUR CLINICAL GROUPS OF FARMER'S LUNG PATIENTS (205 PATIENTS)

\begin{tabular}{|c|c|c|c|c|c|c|c|c|c|c|c|c|c|c|c|c|c|}
\hline & & & \multirow{3}{*}{ Tested } & \multicolumn{2}{|l|}{ Total } & \multicolumn{3}{|c|}{$\begin{array}{l}\text { Group I } \\
(49 \%) \\
\text { Insidious }\end{array}$} & \multicolumn{3}{|c|}{$\begin{array}{c}\text { Group II } \\
(9 \%) \\
\text { Insidious } \\
\text { and Typical }\end{array}$} & \multicolumn{3}{|c|}{$\begin{array}{c}\text { Group III } \\
(32 \%) \\
\text { Typical }\end{array}$} & \multicolumn{3}{|c|}{$\begin{array}{l}\text { Group IV } \\
(10 \%) \text { Rapid } \\
\text { Previously } \\
\text { Insidious } \\
\text { and or } \\
\text { Typical }\end{array}$} \\
\hline & & & & \multicolumn{2}{|c|}{ Positive } & \multirow{2}{*}{ Tested } & \multicolumn{2}{|c|}{ Positive } & \multirow{2}{*}{ Tested } & \multicolumn{2}{|c|}{ Positive } & \multirow{2}{*}{ Tested } & \multicolumn{2}{|c|}{ Positive } & \multirow{2}{*}{ Tested } & \multicolumn{2}{|c|}{ Positive } \\
\hline & & & & No. & $\%$ & & No. & $\%$ & & No. & $\%$ & & No. & $\%$ & & No. & $\%$ \\
\hline $\begin{array}{c}\text { Double-diffusion } \\
\text { Mouldy hay } \\
\text { T.polyspora } \\
\text { M. vulgaris . } \\
\text { Mucor } \\
\text { A. fumigatus }\end{array}$ & $\begin{array}{l} \\
\cdots \\
\cdots \\
\cdots\end{array}$ & $\begin{array}{l}\cdots \\
\cdots \\
\cdots \\
\cdots\end{array}$ & $\begin{array}{l}205 \\
194 \\
193 \\
175 \\
166\end{array}$ & $\begin{array}{r}186 \\
164 \\
101 \\
103 \\
63\end{array}$ & $\begin{array}{l}91 \\
85 \\
52 \\
59 \\
38\end{array}$ & $\begin{array}{r}100 \\
95 \\
95 \\
89 \\
84\end{array}$ & $\begin{array}{l}87 \\
72 \\
46 \\
49 \\
24\end{array}$ & $\begin{array}{l}87 \\
76 \\
48 \\
55 \\
29\end{array}$ & $\begin{array}{l}19 \\
18 \\
18 \\
15 \\
15\end{array}$ & $\begin{array}{r}17 \\
16 \\
9 \\
10 \\
10\end{array}$ & $\begin{array}{l}89 \\
89 \\
50 \\
67 \\
67\end{array}$ & $\begin{array}{l}66 \\
63 \\
63 \\
57 \\
53\end{array}$ & $\begin{array}{l}62 \\
58 \\
35 \\
39 \\
26\end{array}$ & $\begin{array}{l}94 \\
92 \\
56 \\
68 \\
49\end{array}$ & $\begin{array}{l}20 \\
18 \\
17 \\
14 \\
14\end{array}$ & $\begin{array}{r}20 \\
18 \\
11 \\
5 \\
3\end{array}$ & $\begin{array}{r}100 \\
100 \\
65 \\
36 \\
21\end{array}$ \\
\hline $\begin{array}{l}\text { Immuno-electrop } \\
\text { Mouldy hay }\end{array}$ & .10 & . & 205 & $* 182$ & 89 & 100 & 84 & 84 & 19 & 17 & 89 & 66 & 61 & 92 & 20 & 20 & 100 \\
\hline
\end{tabular}

*Including 3 sera which gave reactions not of the $T$. polyspora type. 
FARMING POPULATION

(2a) Farmers with farmer's lung Table VI shows that positive reactions were obtained against extracts of mouldy hay in the double-diffusion test in $91 \%$ of the patients and in $89 \%$ in the immunoelectrophoretic test. There are no statistically significant differences that we wish to stress. The immuno-electrophoretic reactions of $87 \%$ of the sera were produced in the $\dot{A}, B$, and $C$ regions which have been found to be characteristic of the F.L.H. antigens of the type found in $T$. polyspora. The remaining sera regarded as giving positive immunoelectrophoretic reactions, which were not of the F.L.H. ( $T$. polyspora) type, consisted of three sera which in reacting to extracts of mouldy hay gave arcs in other regions. One further serum reacted only to an extract of Streptomyces thermoviolaceus, another of the thermophilic actinomycetes of mouldy hay. The presence of additional sources of F.L.H. antigen other than $T$. polyspora is suggested by the reactions of this small group of four sera.

Positive reactions to extracts of $T$. polyspora were obtained with $85 \%$ of the sera in the doublediffusion test as compared with reactions of $91 \%$ of the sera to extracts of mouldy hay. The extract of the culture of $T$. polyspora on nutrient medium has been found to be less potent than when it is grown on hay, and minor antigenic differences have also been found (Jenkins, 1964). The extract of M. vulgaris gave reactions in $52 \%$, Mucor sp. in $59 \%$, and $A$. fumigatus in $38 \%$ of the total. In both the double-diffusion and immuno-electrophoretic tests, positive reactions to the extracts of mouldy hay were obtained in comparable proportions of patients in all four clinical groups. This is of particular importance in group IV, the rapid onset group, showing that they were similar serologically to the other groups of patients.

The grades of F.L.H. reaction ( $T$. polyspora type) in the immuno-electrophoretic test were classified according to whether arcs were produced in one or more of the regions A, B, and C, corresponding to the electrophoretic spread of the F.L.H. antigens ( $T$. polyspora type) (Fig. 2). In the $87 \%$ of farmer's lung sera that gave reactions in these regions, there were $42 \%$ with grade 3 reactions, i.e., reactions in all three regions, $31 \%$ with grade $2,14 \%$ with grade 1 , and $13 \%$ with grade 0 . Of the grade 2 reactions, $84 \%$ consisted of $A$ and $B$ arcs, with equal numbers of the remainder giving $\mathrm{A}$ and $\mathrm{C}$ or $\mathrm{B}$ and $\mathrm{C}$ arcs. Of the grade 1 reactors, there were $43 \%$ giving $A$ arcs, $50 \%$ giving $B$ arcs, and $7 \%$ giving $\mathrm{C}$ arcs.

A comparison of the clinical features in patients with the various grades of F.L.H. reaction was made in order to see whether there was any relationship between the amount of antibody and the disease (Table VII). Although the incidence of most of the clinical features listed was similar in patients in all grades, even including grade 0 , definite differences were also present. There were in the strongest reactors (grade 3) $91 \%$ of males compared with $68 \%$ to $77 \%$ in the other grades. This may have

TABLE VII

GRADE OF F.L.H. REACTIONS ( $T$. POLYSPORA) AND CLINICAL FEATURES IN FARMER'S LUNG PATIENTS

\begin{tabular}{|c|c|c|c|c|c|c|c|c|c|c|c|c|c|c|c|c|c|c|}
\hline & & & & \multirow{2}{*}{\multicolumn{3}{|c|}{ Total }} & \multicolumn{12}{|c|}{ Grades of F.L.H. Reaction } \\
\hline & & & & & & & \multicolumn{3}{|c|}{$(42 \%)$} & \multicolumn{3}{|c|}{$\begin{array}{c}2 \\
(31 \%)\end{array}$} & \multicolumn{3}{|c|}{$\begin{array}{c}1 \\
(14 \%)\end{array}$} & \multicolumn{3}{|c|}{$\begin{array}{c}0 \\
(13 \%)\end{array}$} \\
\hline & & & & \multirow{2}{*}{ Tested } & \multicolumn{2}{|c|}{ Positive } & \multirow{2}{*}{ Tested - } & \multicolumn{2}{|c|}{ Positive } & \multirow{2}{*}{ Tested } & \multicolumn{2}{|c|}{ Positive } & \multirow{2}{*}{ Tested - } & \multicolumn{2}{|c|}{ Positive } & \multirow{2}{*}{ Tested } & \multicolumn{2}{|c|}{ Positive } \\
\hline & & & & & No. & $\%$ & & No. & $\%$ & & No. & $\%$ & & No. & $\%$ & & No. & $\%$ \\
\hline $\begin{array}{l}\text { No. of patients } \\
\text { Male } \\
\text { Female }\end{array}$ & $\begin{array}{l} \\
\cdots \\
\cdots\end{array}$ & $\begin{array}{l}\cdots \\
\cdots \\
\cdots\end{array}$ & \begin{tabular}{l|}
$\cdots$ \\
$\cdots$ \\
$\cdots$
\end{tabular} & 205 & $\begin{array}{r}167 \\
38\end{array}$ & $\begin{array}{l}81 \\
19\end{array}$ & 87 & $\begin{array}{r}79 \\
8\end{array}$ & $\begin{array}{r}91 \\
9\end{array}$ & 64 & $\begin{array}{l}49 \\
15\end{array}$ & $\begin{array}{l}77 \\
23\end{array}$ & 28 & $\begin{array}{r}19 \\
9\end{array}$ & $\begin{array}{l}68 \\
32 \\
\end{array}$ & 26 & $\begin{array}{r}20 \\
6\end{array}$ & $\begin{array}{l}77 \\
23\end{array}$ \\
\hline $\begin{array}{l}\text { Dyspnoea } \\
\text { Tightness } \\
\text { Wheezing } \\
\text { Cough ... } \\
\text { Expectoration } \\
\text { Haemoptysis } \\
\text { Malaise. . } \\
\text { Fever .. }\end{array}$ & $\begin{array}{l}\cdots \\
\cdots \\
\cdots \\
\cdots \\
\cdots \\
\cdots\end{array}$ & $\begin{array}{l}\cdots \\
\cdots \\
\cdots \\
\cdots \\
\cdots \\
\cdots\end{array}$ & $\begin{array}{l}\ldots \\
\ldots \\
\cdots \\
\cdots \\
\cdots \\
\cdots \\
\cdots\end{array}$ & & $\begin{array}{r}197 \\
57 \\
60 \\
180 \\
108 \\
15 \\
96 \\
99\end{array}$ & $\begin{array}{l}96 \\
28 \\
29 \\
88 \\
53 \\
7 \\
47 \\
48\end{array}$ & & $\begin{array}{r}85 \\
26 \\
29 \\
80 \\
46 \\
6 \\
35 \\
42\end{array}$ & $\begin{array}{l}98 \\
30 \\
33 \\
92 \\
53 \\
7 \\
40 \\
48\end{array}$ & & $\begin{array}{l}60 \\
14 \\
18 \\
55 \\
34 \\
6 \\
31 \\
33\end{array}$ & $\begin{array}{l}94 \\
22 \\
28 \\
86 \\
53 \\
9 \\
48 \\
52\end{array}$ & & $\begin{array}{r}28 \\
12 \\
7 \\
22 \\
15 \\
2 \\
16 \\
16\end{array}$ & $\begin{array}{r}100 \\
43 \\
25 \\
79 \\
54 \\
7 \\
57 \\
57\end{array}$ & & $\begin{array}{r}24 \\
5 \\
6 \\
23 \\
13 \\
1 \\
14 \\
8\end{array}$ & $\begin{array}{r}92 \\
19 \\
23 \\
88 \\
50 \\
4 \\
54 \\
31\end{array}$ \\
\hline $\begin{array}{l}\text { No examined d } \\
\text { Wheezes } \\
\text { Crepitations }\end{array}$ & $\begin{array}{l}\text { duri } \\
\cdots\end{array}$ & $\begin{array}{l}\text { attack } \\
\cdots \\
\cdots \\
\end{array}$ & $\begin{array}{l}\cdots \\
\cdots \\
\cdots\end{array}$ & 172 & $\begin{array}{r}29 \\
139\end{array}$ & $\begin{array}{l}17 \\
81\end{array}$ & 77 & $\begin{array}{r}9 \\
62\end{array}$ & $\begin{array}{l}12 \\
81\end{array}$ & 52 & $\begin{array}{l}10 \\
45\end{array}$ & $\begin{array}{l}19 \\
87\end{array}$ & 23 & $\begin{array}{r}6 \\
15\end{array}$ & $\begin{array}{l}26 \\
65\end{array}$ & 20 & $\begin{array}{r}4 \\
17\end{array}$ & $\begin{array}{l}20 \\
85\end{array}$ \\
\hline $\begin{array}{l}\text { No. of chest rad } \\
\text { attack } \\
\text { Radiograph } \\
\text { farmer's lu }\end{array}$ & $\begin{array}{l}\text { diog } \\
\text { com } \\
\text { lung }\end{array}$ & $\begin{array}{l}\text { phs dur } \\
\text { atible w } \\
\ldots\end{array}$ & $\begin{array}{c}\text { ring } \\
\text { ith } \\
\cdots\end{array}$ & 146 & 95 & 65 & 64 & 37 & 58 & 48 & 33 & 69 & 16 & 14 & 88 & 18 & 11 & 61 \\
\hline
\end{tabular}


TABLE VIII

GRADES OF F.L.H. REACTION AND PERCENTAGES OF POSITIVE REACTIONS TO OTHER EXTRACTS IN FARMER'S LUNG PATIENTS

\begin{tabular}{|c|c|c|c|c|c|c|c|c|c|c|c|c|c|c|c|c|c|}
\hline \multirow{4}{*}{\multicolumn{2}{|c|}{$\begin{array}{c}\text { Double-diffusion } \\
\text { Test Extracts }\end{array}$}} & & \multicolumn{12}{|c|}{ Grade of F.L.H. Reaction } & \multirow{2}{*}{\multicolumn{3}{|c|}{ Total }} \\
\hline & & & \multicolumn{3}{|c|}{3} & \multicolumn{3}{|c|}{2} & \multicolumn{3}{|c|}{1} & \multicolumn{3}{|c|}{0} & & & \\
\hline & & & \multirow{2}{*}{ Tested } & \multicolumn{2}{|c|}{ Positive } & \multirow{2}{*}{ Tested } & \multicolumn{2}{|c|}{ Positive } & \multirow{2}{*}{ Tested } & \multicolumn{2}{|c|}{ Positive } & \multirow{2}{*}{ Tested } & \multicolumn{2}{|c|}{ Positive } & \multirow{2}{*}{ Tested - } & \multicolumn{2}{|c|}{ Positive } \\
\hline & & & & No. & $\%$ & & No. & $\%$ & & No. & $\%$ & & No. & $\%$ & & No. & $\%$ \\
\hline $\begin{array}{l}\text { Mouldy hay ( } 3 \\
T . \text { polyspora } \\
M \text {. vulgaris } \\
\text { Mucor sp. } \\
\text { A. fumigatus }\end{array}$ & $\begin{array}{l}\cdots \\
\cdots \\
\cdots \\
\cdots\end{array}$ & \begin{tabular}{l|}
$\ldots$ \\
$\ldots$ \\
$\cdots$ \\
$\cdots$
\end{tabular} & $\begin{array}{l}87 \\
82 \\
82 \\
67 \\
65\end{array}$ & $\begin{array}{l}87 \\
82 \\
54 \\
49 \\
31\end{array}$ & $\begin{array}{r}100 \\
100 \\
66 \\
73 \\
48\end{array}$ & $\begin{array}{l}64 \\
60 \\
59 \\
55 \\
50\end{array}$ & $\begin{array}{l}64 \\
60 \\
37 \\
33 \\
20\end{array}$ & $\begin{array}{r}100 \\
100 \\
63 \\
60 \\
40\end{array}$ & $\begin{array}{l}28 \\
26 \\
26 \\
28 \\
27\end{array}$ & $\begin{array}{r}28 \\
19 \\
9 \\
14 \\
10\end{array}$ & $\begin{array}{r}100 \\
73 \\
35 \\
50 \\
37\end{array}$ & $\begin{array}{l}26 \\
26 \\
26 \\
25 \\
24\end{array}$ & $\begin{array}{l}7 \\
3 \\
1 \\
7 \\
2\end{array}$ & $\begin{array}{r}27 \\
12 \\
4 \\
28 \\
8\end{array}$ & $\begin{array}{l}205 \\
194 \\
193 \\
175 \\
166\end{array}$ & $\begin{array}{r}186 \\
164 \\
101 \\
103 \\
63\end{array}$ & $\begin{array}{l}91 \\
85 \\
52 \\
59 \\
38\end{array}$ \\
\hline
\end{tabular}

been due to the heavier exposure of the male to the dust. In grade 0 only $31 \%$ of patients had fever compared with $48 \%$ to $57 \%$ in the other grades, suggesting that in this grade the absence of precipitins may have been related to the intensity of the systemic reaction.

There was also a correlation between the grade of F.L.H. reaction and the incidence of reactions in double-diffusion tests to other flora of the mouldy hay (Table VIII), the proportion of precipitation reactions to extracts of $M$. vulgaris and Mucor sp. being greater in the higher grades. There were in the grade 3 reactors $66 \%$ and $73 \%$ respectively, as compared with $63 \%$ and $60 \%$ in grade $2,35 \%$ and $50 \%$ in grade 1 , and $4 \%$ and $28 \%$ in grade 0 . These differences were statistically significant, $P>0.001$. There were also more reactions to the extract of A. fumigatus, $48 \%$ in the grade 3 sera compared with $40 \%$ in grade $2,37 \%$ in grade 1 , and $8 \%$ in grade 0 . These differences were statistically significant, $P=0.01$.

Table IX shows that the higher the grade of F.L.H. reaction, i.e., the more antibody present, the greater was the number of attacks. In the patients with grade 3 sera, there were $44 \%$ with three or more attacks, compared with $31 \%$ in grade $2,17 \%$ in grade 1 , and $14 \%$ in grade 0 . These differences were statistically significant, $\mathrm{p}=0.05$. The degree of clinical sensitivity to the dust was

TABLE IX

GRADE OF F.L.H. REACTION AND NO. OF ATTACKS OF FARMER'S LUNG IN FARMER'S LUNG PATIENTS

\begin{tabular}{c|c|c|c|c|c}
\hline $\begin{array}{c}\text { Grade of } \\
\text { F.L.H. } \\
\text { Reaction }\end{array}$ & $\begin{array}{c}\text { No. of } \\
\text { Patients } \\
\text { Assessed }\end{array}$ & $\begin{array}{c}\mid c \\
(\%)\end{array}$ & $\begin{array}{c}2 \\
(\%)\end{array}$ & $\begin{array}{c}3 \\
(\%)\end{array}$ & $\begin{array}{c}\text { Nor or } \\
\text { More } \\
(\%)\end{array}$ \\
\hline 0 & 21 & 76 & 10 & 4 & 10 \\
1 & 29 & 62 & 21 & 7 & 10 \\
2 & 61 & 44 & 25 & 16 & 15 \\
3 & 86 & 34 & 22 & 20 & 24 \\
\hline
\end{tabular}

* Supplemented by additional patients examined after main analysis because of small numbers with information available. assessed by the length of exposure required to $\stackrel{\text { S }}{S}$ provoke symptoms. Table $X$ shows that $70 \%$ and 은 $62 \%$ respectively of the patients with grade 0 and $\vec{c}$ grade 1 sera were affected only by long exposures @ू (that is their sensitivity was low) compared with $27 \%$ and $21 \%$ in grade 2 and grade 3 . On the other hand, $29 \%$ and $31 \%$ respectively of the patients with grade 2 and grade 3 sera were affected by $\mathscr{\odot}$ short exposure (that is their degree of sensitivity was high) as compared with $15 \%$ and $7 \%$ respectively in the patients with grades 0 and 1 sera. The statistical significance of these differences was $P>0.001$.

TABLE X

GRADE OF F.L.H. REACTION AND SEVERITY OF FARMER'S LUNG IN FARMER'S LUNG PATIENTS

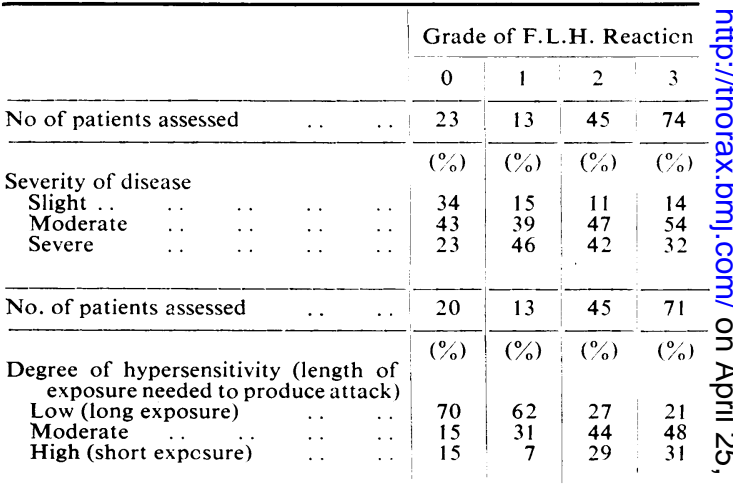

Differences were also present in the severity of $\underset{\omega}{N}$ the attacks in patients with the various grades of $\widetilde{C}$ serological reaction, there being more patients witho slight reactions and fewer patients with severe $\frac{\mathscr{D}}{\Phi}$ reactions among the patients with grade 0 than in $\stackrel{\mathcal{Q}}{+}$ those with grades 1,2 , and 3 sera (Table $X$ ). 0 Although this difference was not statistically significant, it is suggested, like the other findings, $\stackrel{\odot}{\overparen{D}}$ that the presence and amount of precipitating $\underset{\mathbb{D}}{\mathbb{Q}}$ antibody were related to the severity of the clinical manifestations. 
FIG. 4. Grade of F.L.H. reaction of sera of farmers exposed to mouldy hay.

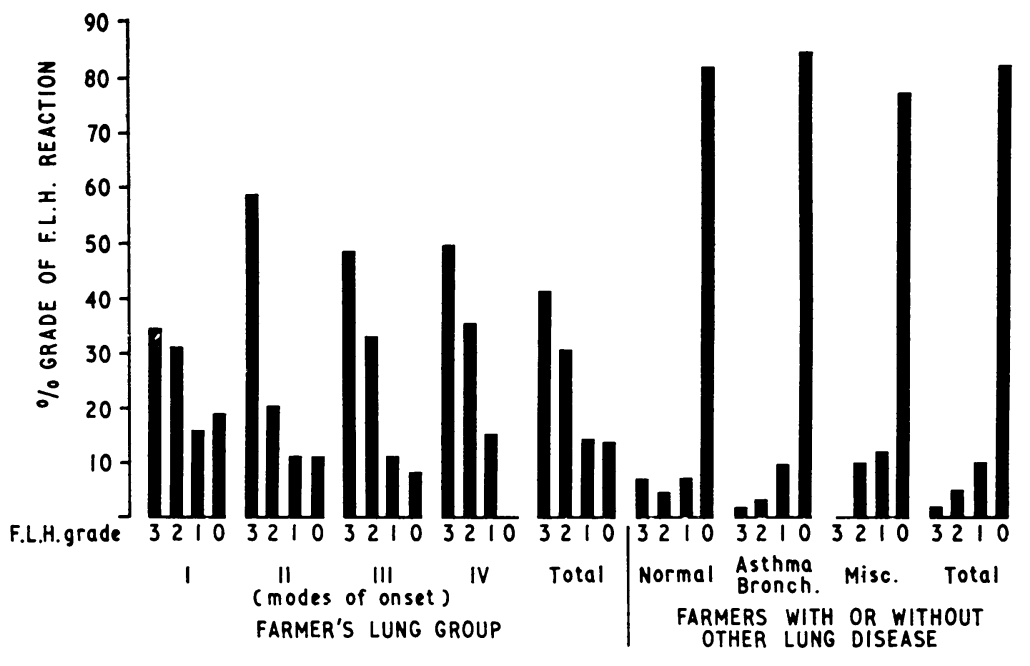

TABLE XI

The clinicians were asked to answer the question, Do the symptoms, signs, and duration suggest that the attacks were slight, moderate, or severe? We felt that the differences between slight and severe were readily decided, and the remainder of the patients would be regarded as having 'moderate' attacks.

These grades of severity were not known to the clinicians before the serological results, and there were no important differences in the grades of severity of disease in the different groups of onset.

The grades of F.L.H. reaction in the four clinical groups of modes of onset are shown in Figure 4. There were fewer patients with grade 3 sera and more with grade 0 sera in the group of patients whose disease started insidiously than in the other groups. The weaker serological reactions in this group may be related to the gradual mode of onset of the disease.

The group of 12 sera from Icelandic patients with farmer's lung all gave typical F.L.H. reactions: grade 3 in six; grade 2 in three; and grade 1 in three cases.

(2b) Farmers with or without other lung disease Table XI shows that reactions were given in $32 \%$ of the normal farmers, in $34 \%$ of the farmers with asthma or bronchitis, and in $39 \%$ of the farmers with other lung diseases in double-diffusion tests with extracts of mouldy hay. Reactions to the extract of $T$. polyspora were given in $19 \%, 30 \%$, and $20 \%$ respectively. There were also low proportions of reactions to the other extracts tested.

In the immuno-electrophoretic test, F.L.H. reactions were given by $18 \%$ of normal farmers, $15^{\circ} \%$ of the farmers with asthma and bronchitis, and $21 \%$ of those with other lung diseases. Figure 4 shows 
TABLE XII

IMMUNO-ELECTROPHORETIC TEST-MOUIDY HAY EXTRACT

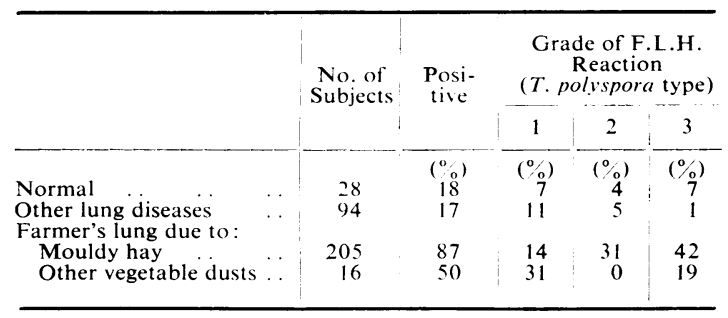

who gave positive reactions, the diagnosis of farmer's lung could not be excluded in at least two cases. One was a threshing contractor in whom the diagnosis was complicated by hypertension and left ventricular enlargement; the second patient, in whom a diagnosis of diffuse interstitial fibrosis had been made, had a long history of exposure to baled hay though without any definite attacks. Four of the positive reactors were diagnosed as having pulmonary fibrosis, in one patient possibly due to sarcoidosis, and one patient had chronic tuberculosis and asthma.

(3) PATIENTS WITH FARMER'S LUNG DUE TO OTHER VEGETABLE DUSTS Tests were performed on a group of 16 sera from patients suffering from farmer's lung due to mouldy corn (9), mouldy barley and barley straw (5), and sweating oats (2). The clinical features consisted of dyspnoea in all cases; tightness of the chest (6); wheezing (5); cough (10); malaise (5); fever (8); crepitations (7 out of 11); loss of weight (1); radiographic evidence compatible with the diagnosis ( 3 out of 5).

In double-diffusion tests, eight reacted to mouldy hay and to $T$. polyspora, one to $M$. vulgaris, two to Mucor sp., and none to A. fumigatus. In the immunoelectrophoretic test, eight sera $(50 \%)$ gave F.L.H. reactions ( $T$. polyspora type) to extracts of mouldy hay. Although the numbers are small, these results suggest that there was a lower content in the other cereal dusts of the flora found in mouldy hay.

\section{COMPARISONS OF THE MOULDY HAY EXTRACTS}

Table XIII shows that the extract of $\mathrm{H} 44$ gave much lower proportions of reactions with sera of grades 1 , 2 , and 3 than the extracts of the other two mouldy hays prepared by growing a mixed inoculum of the organisms from $\mathrm{H} 44$ on moistened sterile hay under favourable conditions. This finding shows the importance of using mouldy hays capable of providing potent extracts and is also relevant in that $\mathrm{H} 44$ was used in the previous studies (Pepys and others, 1962; Williams, 1963a, b). Its lack of potency influenced the conclusions derived from its use, and $\frac{\overrightarrow{\bar{S}}}{\frac{\vec{O}}{0}}$ this will be discussed again later.

Further mouldy hays were prepared by permitting $\frac{\bar{\sigma}}{\bar{c}}$ the hay to become mouldy in the laboratory without $\mathbb{\mathbb { D }}$ any added inoculum or incubation, thus simulating the self-heating of mouldy hay under naturalos conditions. The mouldy hay V4 gave reactions $\vec{O}$ comparable to those of other mouldy hays. V17, $\vec{\overrightarrow{ }}$ however, differed strikingly from the others tested $\vec{\sigma}$ in this and previous studies, giving more frequent reactions with control sera. Reactions were obtained $x$ in double-diffusion and immuno-electrophoretic $\stackrel{N}{O}$

TABLE XIII

IMMUNO-ELECTROPHORETIC TEST REACTIONS IN FARMER'S LUNG PATIENTS TO MOULDY HAY EXTRACTS IN RELATION TO GRADE OF F.L.H. REACTION (133 SERA)

\begin{tabular}{|c|c|c|c|}
\hline \multirow{2}{*}{$\begin{array}{c}\text { Grade of } \\
\text { F.L.H. Reaction }\end{array}$} & \multicolumn{3}{|c|}{ Mouldy Hays } \\
\hline & $\begin{array}{r}\mathrm{H} 44 \\
(\%)\end{array}$ & $\begin{array}{l}\mathrm{H} / \mathrm{b} \\
(\%)\end{array}$ & $\begin{array}{r}\mathrm{L} 8 \\
(\%) \\
\end{array}$ \\
\hline $\begin{array}{l}1 \\
2 \\
3\end{array}$ & $\begin{array}{l}38 \\
40 \\
70\end{array}$ & $\begin{array}{r}70 \\
96 \\
100\end{array}$ & $\begin{array}{r}65 \\
98 \\
100\end{array}$ \\
\hline
\end{tabular}

tests as follows: in 22 normal sera, 11 and 8 respectively; in 25 sera from asthmatics, 16 and $14 \frac{\bar{\partial}}{2}$

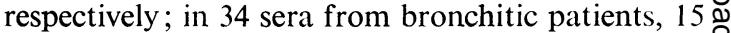
and 9 respectively; and in 22 patients with inter-市 stitial fibrosis, 11 and only 1 respectively. The immuno-electrophoretic reactions of this extract $\frac{\text { 응 }}{3}$ lay well away from the F.L.H. reaction ( $T$. polyspora type) towards the anode (Fig. 2). The significance of this reaction is not known, but it emphasizes the need to use the F.L.H. pattern of $T$. polyspora as a guide for the present.

\section{REACTIONS TO $M$. vulgaris}

The extract of $M$. vulgaris gave reactions in double- $\delta$ diffusion tests with $52 \%$ of the sera. Since this extract contains antigens which give reactions in 을 the $\mathrm{C}$ region, this value corresponds well with the finding that in the immuno-electrophoretic test with extracts of mouldy hay, $48 \%$ of the sera gave $\frac{\mathrm{N}}{\mathrm{N}}$ reactions in the $\mathrm{C}$ region. Only $7 \%$ of the reactions $\mathrm{or}$ to the mouldy hay extracts were reactions solely in $N$ the $\mathrm{C}$ region. As stated earlier, $M$. vulgaris and $\underset{\omega}{N}$ $T$. polyspora have a common antigen which produced 0 reactions in the $\mathrm{C}$ region.

TRICHLORACETIC ACID FRACTIONS OF $T$. polyspora EXTRACT

The antigens precipitated from the culture filtrate extract of $T$. polyspora by trichloracetic acid gave $\stackrel{\mathbb{D}}{\square}$ reactions in the $A$ and $B$ regions, whereas the $\stackrel{\mathbb{Q}}{\perp}$ antigens present in the supernatant gave reactions in the $\mathrm{C}$ region (Fig. 3). The $\mathrm{C}$ antigen in the 
supernatant was compared directly with the antigen produced by Kobayashi and others (1963) by the extraction of mouldy hay with trichloracetic acid solution. Eoth preparations gave reactions of identity in the agar-gel test and were capable of inhibiting each other's reactions.

\section{INHALATION TESTS}

Systemic and pulmonary reactions of the type encountered in farmer's lung have been reported in five affected subjects as a result of the inhalation of an extract of the culture filtrate of $T$. polyspora grown on nutrient agar (Pepys and others, 1963). Further tests have been performed with the trichloracetic acid fractions of the $T$. polyspora extract in two additional patients and in repetition of the tests on one of the previous patients. Tests were also performed with extracts of mouldy hay and of M. vulgaris.

The number of controls was increased from one in the previous study to four by the testing of a further three subjects. The four controls consisted of a farmer and an agricultural inspector, both with asthma only, and two urban patients with asthma. No reactions, systemic or pulmonary, resulted in these patients from the inhalation of the highest concentration of $T$. polyspora used, $10 \mathrm{mg} . / \mathrm{ml}$, given for the longest time, 15 minutes.

The seven patients in the farmer's lung group consisted of two patients with a typical onset and without bronchial reactions; one patient with an insidious onset but with wheezing noted from the beginning; two patients with asthma and one with bronchitis which preceded the farmer's lung; and one patient in whom bronchial reactions appeared rapidly on exposure to the dust of mouldy hay.

All these subjects gave systemic or pulmonary reactions to the $T$. polyspora extract and, where tested, to its fractions. An immediate reaction was obtained in only one, and in this case to the test with the extract of $M$. vulgaris. The systemic reactions, consisting of aches and pains and malaise, resembled the complaints of the actual disease and came on several hours after the test, being accompanied in all except one case by a rise in temperature maximal between five and seven hours. Disturbances of pulmonary function were demonstrable at the same time, pulmonary symptoms and signs only becoming obvious where strong reactions were provoked.

The inhalation tests (Table XIV) show that the $\mathrm{A}$ and $\mathrm{B}$ fraction and the $\mathrm{C}$ fraction of $T$. polyspora

TABLE XIV

INHALATION TESTS

\begin{tabular}{|c|c|c|c|c|c|c|c|c|c|}
\hline \multirow[b]{2}{*}{ Patient } & \multirow[b]{2}{*}{$\begin{array}{l}\text { Type of Onset } \\
\text { and } \\
\text { F.L.H. Grade of } \\
\text { Reaction }\end{array}$} & \multirow[b]{2}{*}{ Test Extract } & \multirow[b]{2}{*}{$\begin{array}{l}\text { Conc. } \\
\text { (mg. ml.) }\end{array}$} & \multirow[b]{2}{*}{$\begin{array}{c}\text { Duration } \\
\text { of } \\
\text { Inhalation } \\
\text { (min.) }\end{array}$} & \multirow[b]{2}{*}{$\begin{array}{l}\text { Rise } \\
\text { in } \\
\text { Temp. } \\
\text { to }{ }^{\circ} \mathbf{F} \text {. }\end{array}$} & \multicolumn{4}{|c|}{ Fall In } \\
\hline & & & & & & $\begin{array}{l}\text { F.V.C. (ml.) } \\
\text { from to }\end{array}$ & $\begin{array}{l}\text { F.E.V. (ml.) } \\
\text { from to }\end{array}$ & $\begin{array}{c}\text { Static } \\
\text { Compliance } \\
\left.\text { (l. cm. } \mathrm{H}_{2} \mathrm{O}\right) \\
\text { from to }\end{array}$ & $\begin{array}{l}\text { DLco } \\
\text { from to }\end{array}$ \\
\hline 1 & Typical Grade 3 & $\begin{array}{l}\text { (a) } T \text {. polyspora } \\
\text { (b) A and B fraction } \\
\text { (c) } \mathrm{C} \text { fraction } \\
\text { (d) } \mathrm{C} \text { fraction } \\
\text { (e) } M \text {. vulgaris }\end{array}$ & $\begin{array}{l}10 \\
10 \\
10 \\
10 \\
10\end{array}$ & $\begin{array}{r}10 \\
10 \\
6 \\
12 \\
10\end{array}$ & $\begin{array}{l}102 \cdot 5 \\
99 \cdot 5 \\
\text { No rise } \\
100 \cdot 5 \\
\text { No rise }\end{array}$ & 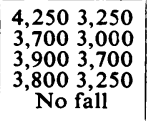 & $\begin{array}{c}3,3002,800 \\
2,8502,100 \\
3,1002,700 \\
3,1002,200 \\
\text { No fall }\end{array}$ & $\begin{array}{l}0 \cdot 1810 \cdot 094 \\
0 \cdot 2190 \cdot 082 \\
0 \cdot 1400 \cdot 120 \\
0 \cdot 1430.074 \\
\text { No fall }\end{array}$ & $\begin{array}{l}\text { NA } \\
\text { NA } \\
\text { NA } \\
\text { NA } \\
\text { NA }\end{array}$ \\
\hline 2 & Typical Grade 2 & $\begin{array}{l}\text { (a) } T \text {. polyspora } \\
\text { (b) Mouldy hay }\end{array}$ & $\begin{array}{l}10 \\
10\end{array}$ & $\begin{array}{r}10 \\
7\end{array}$ & $\begin{array}{c}\text { No rise } \\
99.5\end{array}$ & $\begin{array}{l}\text { No fall } \\
\text { No fall }\end{array}$ & $\begin{array}{c}\text { No fall } \\
2,790 \text { 2,300 }\end{array}$ & $\begin{array}{c}\text { No fall } \\
0 \cdot 1460 \cdot 102\end{array}$ & $\begin{array}{l}\text { NA } \\
\text { NA }\end{array}$ \\
\hline 3 & $\begin{array}{l}\text { Insidious with } \\
\text { wheezing } \\
\text { Grade } 3\end{array}$ & $\begin{array}{l}\text { (a) C fraction } \\
\text { (b) } \mathrm{A} \text { and } \mathrm{B} \text { fraction } \\
\text { (c) } \mathrm{A} \text { and } \mathrm{B} \text { fraction } \\
\text { (d) } T \text {. polyspora } \\
\text { grown on hay }\end{array}$ & $\begin{array}{r}10 \\
1 \\
10 \\
10\end{array}$ & $\begin{array}{l}10 \\
10 \\
10 \\
10\end{array}$ & $\begin{array}{c}99 \\
98 \cdot 8 \\
101 \\
98 \cdot 8\end{array}$ & 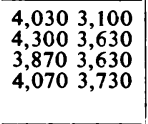 & 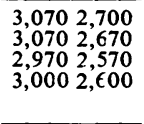 & $\begin{array}{l}\text { No fall } \\
\text { No fall } \\
\text { No fall } \\
\text { NA }\end{array}$ & $\begin{array}{l}\text { No fall } \\
14 \cdot 1 \\
\text { No fall } \\
15 \quad 8\end{array}$ \\
\hline 4 & $\begin{array}{l}\text { Asthma and } \\
\text { farmer's lung } \\
\text { Grade } 3\end{array}$ & $\begin{array}{l}\text { 1st Test } \\
\text { (a) } T \text {. polyspora } \\
\text { Repeat tests } \\
\text { (a) A and B fraction } \\
\text { (b) C fraction } \\
\text { (c) A and B fraction }\end{array}$ & $\begin{array}{l}10 \\
10 \\
10 \\
10\end{array}$ & $\begin{array}{r}10 \\
5 \\
5 \\
3\end{array}$ & $\begin{array}{c}98 \cdot 8 \\
102 \\
99 \\
101 \cdot 5\end{array}$ & $\begin{array}{cc}\text { No fall } \\
3,670 & 3,170 \\
3,600 & 3,370 \\
3,470 & 2,970\end{array}$ & $\begin{array}{c}\text { No fall } \\
2,230 \\
2,070 \\
2,2702,070 \\
2,1001,700\end{array}$ & $\begin{array}{c}\text { NA } \\
\text { No fall } \\
0.230 \cdot 15\end{array}$ & $\begin{array}{rr}13 \cdot 4 & 9 \cdot 7 \\
13 \cdot 2 & 9 \cdot 4 \\
\text { No fall }\end{array}$ \\
\hline 5 & $\begin{array}{l}\text { Asthma and } \\
\text { farmer's lung } \\
\text { Grade } 1\end{array}$ & $\begin{array}{l}\text { (a) Mouldy hay } \\
\text { (b) T. polyspora }\end{array}$ & $\begin{array}{l}10 \\
10\end{array}$ & $\begin{array}{l}10 \\
10\end{array}$ & $\begin{array}{l}98 \cdot 7 \\
99 \cdot 4\end{array}$ & $\begin{array}{l}\text { No change } \\
3,1503,000\end{array}$ & $\begin{array}{ll}1,600 & 1,400 \\
1,500 & 1,400\end{array}$ & $\begin{array}{l}\text { NA } \\
\text { NA }\end{array}$ & $\begin{array}{l}\text { NA } \\
\text { NA }\end{array}$ \\
\hline 6 & $\begin{array}{l}\text { Bronchitis and } \\
\text { farmer's lung } \\
\text { Grade } 2\end{array}$ & (a) $T$. polyspora & 10 & 10 & No rise & No fall & $1,1201,0 \leq 0$ & 0.1900 .078 & NA \\
\hline 7 & $\begin{array}{l}\text { Farmer's lung } \\
\text { and/later asthma } \\
\text { Grade } 1\end{array}$ & $\begin{array}{l}\text { (a) } T \text {. polyspora } \\
\text { (b) } T \text {. polyspora } \\
\text { (c) } M \text {. vulgaris }\end{array}$ & $\begin{array}{l}10 \\
10 \\
10\end{array}$ & $\begin{array}{r}7 \\
15 \\
10\end{array}$ & $\begin{array}{c}\text { No rise } \\
100\end{array}$ & 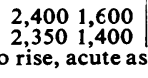 & $\begin{array}{cc}1,050 & 750 \\
900 & 650 \\
\text { thmatic reacti }\end{array}$ & $\begin{array}{l}\text { No fall } \\
0.057 \\
0.024 \\
\text { on }\end{array}$ & $\begin{array}{l}\text { NA } \\
\text { NA } \\
\text { NA }\end{array}$ \\
\hline
\end{tabular}

NA, not available. 
were both capable of provoking reactions. In patient 2 the extract of mouldy hay provoked a more vigorous response than the $T$. polyspora extract. This may be important in selecting antigenic extracts for such tests. In general, the higher the concentration of the antigen and the longer the inhalation, the more vigorous was the reaction produced. Thus in patient 1 , inhalation of the $\mathrm{C}$ fraction for $12 \mathrm{~min}$. resulted in a temperature of $100.5^{\circ} \mathrm{F}$. and a fall in static compliance, whereas the $6 \mathrm{~min}$. inhalation provoked no reactions. In patient 3 , the $A$ and $B$ fraction at $10 \mathrm{mg} . / \mathrm{ml}$. provoked a temperature of $101^{\circ} \mathrm{F}$. as compared with $98 \cdot 8^{\circ} \mathrm{F}$. after the test with a $1 \mathrm{mg}$. $/ \mathrm{ml}$. concentration. Patient 7 gave a vigorous reaction to $T$. polyspora extract given for $15 \mathrm{~min}$. compared with a slight reaction to the $7 \mathrm{~min}$. inhalation.

The pulmonary function tests showed that the changes in ventilation were not marked, except in patient 7 , who will be discussed later. The $D_{L c o}$ was measured in patients 3 and 4 , both of whom showed decreases except in response to test $(c)$ in each case. The minute volume had however risen sharply during test $(c)$ in patient 3 from 12.4 to $17 \cdot 81 . / \mathrm{min}$. and in patient 4 from 10 to $161 . / \mathrm{min}$., which probably accounts for the absence of change in $D_{\text {Lco. }}$. Crepitations appeared in patient 1 after the inhalation of the A and B fraction (test $(b)$ ) and the $\mathrm{C}$ fraction (test $(d)$ ), and in patient 7 after the inhalation of $T$. polyspora extract (test $(b)$ ).

The tests show that in patients in whom farmer's lung is complicated by bronchial disease preceding or following the farmer's lung, challenge with specific antigens can provoke a febrile systemic reaction and a pulmonary reaction coming on after some hours and resembling the features regarded as characteristic of farmer's lung. Patient 7 is of interest since he began to have a rapid onset of respiratory symptoms in response to exposure to mouldy hay only after he had had attacks of farmer's lung. The inhalation of the $T$. polyspora extract provoked systemic and pulmonary symptoms like those of farmer's lung, whereas an unexpected acute asthmatic reaction followed the test with the extract of $M$. vulgaris.

More detailed testing on more typical cases is required, but our findings in this group support the suggestions that in some cases of farmer's lung there may be differences from the classical descrip. tions in the mode of onset and in the clinical features of the disease.

\section{DISCUSSION}

The presence of precipitins against 'farmer's lung hay' (F.L.H.) antigens derived from $T$. polyspora and $M$. vulgaris is evidence of exposure to mouldy hay, since they are not found in subjects who have not been so exposed. The positive reactions to extracts of mouldy hay, which were obtained in the immuno-electrophoretic test with $89 \%$ of the sera of patients with farmer's lung attributed to mouldy hay, were in $87 \%$ of cases of the type produced by antigens present in $T$. polyspora; the remaining $2 \%$ gave reactions not of this type. In seeking for the explanation of the negative reactions in $11 \%$ of the farmer's lung subjects, several possibilities must be considered. Other sources of antigen may have been responsible for the disease, and this may apply particularly to the patients affected by mouldy cereal dusts other than mouldy hay, of whom only one-half gave positive reactions. Some limited evidence for this was given by the reactions obtained with three sera to other antigens in extracts of mouldy hay and with one serum to an extract of another thermophilic actinomycete, Streptomyces thermoviolaceus. More sensitive serological tests may also be of value, and with the identification of known sources of antigen these can now be attempted. Another possible explanation for the negative reactions in affected subjects is that the precipitins against the F.L.H. antigens may be present as a result of exposure to mouldy hay and may be playing an immuno-pathological role in some cases only or not at all. In sensitization by complex micro-organisms the reactions elicited may be mediated by more than one type of hypersensitivity for which different antigenic components may be responsible. The possibility of delayed hypersensitivity reactions of the tuberculin type as a cause of farmer's lung, with or without the participation of precipitin-mediated reactions, must be considered. Tests for delayed hypersensitivity also require pure antigens from known sources, and the recent findings may be of value in this respect as well.

Another aspect of the serological reactions that requires explanation is the appreciable group of $15 \%$ to $21 \%$ of farmers without farmer's lung whose sera gave F.L.H. reactions ( $T$. polyspora type). The significance of these antibodies will need to be assessed by the follow-up of these subjects. The fact that unaffected farmers gave positive serological reactions shows that these reactions are not in themselves diagnostic of farmer's lung though they provide supporting evidence if the features of the disease are present.

The use of the pattern of arcs labelled A, B, and C, produced by the F.L.H. antigens ( $T$. polyspora type) in the immuno-electrophoretic test, as a means of grading the intensity of the precipitation 
reaction showed interesting correlations with other findings. In addition to the high proportion of positive reactions in farmer's lung patients, their sera also gave much higher grades of reaction than the sera of non-affected farmers. The grade 3 sera (reacting to all three F.L.H. antigens) gave higher proportions of reactions to the extracts of the other flora of mouldy hay, and the group of patients with grade 3 sera included a higher proportion of males, than the patients with the weaker grades of reaction. This suggests that the subjects with grade 3 sera were more heavily exposed to the mouldy hay, as would be expected in male farmers. The frequency and severity of attacks and the degree of sensitivity to the dust were also greater in the patients with the higher grades of serological reaction. These findings suggest that the precipitins are concerned in or run parallel with the pathogenetic mechanisms of the disease.

The immuno-electrophoretic test gave results which seem to be more significant clinically than those of the double-diffusion test. In patients with farmer's lung, similar proportions of reactions were obtained to both tests, but in the normal farmers and in those with other pulmonary diseases, almost twice as many positive reactions were obtained to extracts of mouldy hay and of $T$. polyspora in the more sensitive double-diffusion test than in the immuno-electrophoresis test. This indicates that there is less antibody in the unaffected than in the affected farmers and may account for the absence of farmer's lung reactions in them.

The sera of subjects not exposed to mouldy hay which gave weak positive reactions to extracts of mouldy hay in double-diffusion tests in the previous report by Pepys and others (1962) gave no reactions in the immuno-electrophoretic test. In this respect the reactions of the non-exposed subjects differ from those obtained in double-diffusion tests in exposed farmers with or without farmer's lung, suggesting either that different antigens were responsible or that the amount of antibody in these non-farming subjects was very low.

The addition of trichloracetic acid to an extract of $T$. polyspora produced a deposit which contained the F.L.H. antigens $A$ and $B$ and a supernatant solution containing antigen $C$. Inhalations of antigens $A$ and $B$ and of antigen $C$ both provoked systemic and pulmonary manifestations of farmer's lung in affected subjects. The antigen $C$ in the supernatant is identical with the antigen of Kobayashi and others (1963) which was prepared by extracting mouldy hay with a trichloracetic acid solution, evidently leaving the antigens $A$ and $B$ in the hay. They reported a reaction of the farmer's lung type in a single patient who was tested by the inhalation of their extract.

Kobayashi and others (1963) claim that their antigen was more specific than the usual Coca's fluid extract of mouldy hay, because it gave reactions only in patients with farmer's lung. We have, however, shown that more than one half of our patients gave precipitin reactions with antigens $A$ and $B$ but not with antigen $C$.

The farmer's lung sera which gave grade 3 F.L.H. reactions, that is reactions to the $C$ as well as to the $\mathrm{A}$ and $\mathrm{B}$ antigens, contained the largest variety and amount of antibodies and were obtained from patients with the most frequent and severe attacks. Positive reactions to antigens of the $C$ type would therefore be obtained chiefly in this group of most sensitive subjects, thus giving an impression of greater specificity. Extracts containing $\mathrm{A}$ and $\mathrm{B}$ antigens as well, however, give positive reactions not only in a much larger proportion of affected subjects but also in a number of exposed but unaffected farmers.

Mouldy hays vary in their content of $T$. polyspora. A lower proportion of positive sera gave reactions to $\mathrm{H} 44$ than to the other mouldy hay extracts and to $T$. polyspora. In previous investigations by Pepys and others (1962) and by Williams (1963a, b), the fine dust fraction of $\mathrm{H} 44$ was used as a source of actinomycete antigen. This extract of the fine dust of $\mathrm{H} 44$ was the only one of the fungal and other extracts tested which gave any inhibition of the reactions to the additional antigens of mouldy hay when it was used to absorb the sera of patients with farmer's lung. This inhibition was, however, weak, and since the extract also failed to provoke a reaction in the inhalation test we thought that the fine dust did not contain the source of the additional antigens, although these were found in the coarse dust. We now think that the extract contained only small amounts of $T$. polyspora antigen. This assumption is supported by the fact that the inoculation of a mixed suspension of the organism of $\mathrm{H} 44$ into sterile hay gave under favourable conditions good growth of $T$. polyspora and an abundant supply of its antigens (Pepys and others, 1563). It was these results that led to the demonstration of $T$. polyspora as an important source of F.L.H. antigen, and it was fortuitous that $\mathrm{H} 44$ was used in the previous study, from which it was concluded that the antigens relevant to farmer's lung probably arose from breakdown products of the hay itself.

The potency of the antigens of $T$. polyspora demonstrated in man is also evident in cattle which have been investigated for the disease known as fog-fever, a respiratory illness which in some cases 
resembles farmer's lung. Although no F.L.H. precipitins were found in the sera of animals in unaffected herds and only small numbers in other animals, almost two-thirds of the cattle suffering from fog-fever or from herds in which it was present had F.L.H. precipitins of the $T$. polyspora type in their serum (Jenkins, 1964).

Less than half of the patients with farmer's lung had typical acute attacks to start with or at some time in the course of the disease, and in the remainder it developed insidiously, particularly in farmers who were constantly exposed. The immediate or almost immediate reactions that may appear in subjects who have become very sensitive may be deceptive if the history of previous insidious or typical attacks has not been elicited. Most of the typical clinical features are present as frequently in this group as in those with the other types of onset. Clinical differences are probably due to variations in the degree of sensitivity of the subject and of the intensity of exposure.

Inhalation tests with extracts of $T$. polyspora and of mouldy hay in patients in whom farmer's lung was complicated by preceding allergic asthma or bronchitis, or by the appearance of asthmatic reactions after the farmer's lung, resulted in febrile systemic reactions and pulmonary reactions like those of farmer's lung. These responses came on some hours after exposure and support the view that a small proportion of the patients with farmer's lung may have, at the same time or as a result, bronchial manifestations as well.

The inclusion of an onset like that of 'asthmatic bronchitis' by Staines and Forman (1961) is probably responsible for the presence of $17 \%$ (16 out of 94 ) of patients with a past history of allergic reactions in their farmer's lung patients. Precipitin tests on the sera of their patients were made in the investigation by Pepys and others (1962). Positive reactions with the farmers' sera were obtained in doublediffusion tests with extracts of mouldy hay only with the sera of those farmers regarded as suffering from farmer's lung. This is clearly a difficult problem to resolve, but it seems that some of these patients may have been suffering from asthma or bronchitis rather than from farmer's lung, particularly since the present study has shown that precipitin reactions of the F.L.H. type may be obtained in normal farmers and in farmers with asthma and bronchitis.

In order to minimize this problem, farmers with previous asthma, bronchitis or other lung disease were excluded from the farmer's lung group unless additional supporting clinical evidence was present. The farmer's lung group included four patients with asthma, and if hay fever and rhinitis are included, there were less than $5 \%$ of subjects in this group with a history suggestive of atopic allergic sensitivity. It is not unlikely that the grouping of patients employed here may err in the opposite direction to that of Staines and Forman (1961) by excluding patients with less familiar forms of farmer's lung, and there will almost certainly be a group in whom a final decision may not be reached.

Studies of pulmonary function may help to distinguish between patients with bronchial reactions associated with disturbances of ventilatory function and patients with farmer's lung in whom the reaction in the peripheral part of the bronchopulmonary tree results in impaired diffusion of gases and decreased lung compliance. On the one hand, these latter features may not be present at the time of examination, and, on the other hand, Dickie and Rankin (1960) have listed a large number of disorders with similar physiological findings, including, for example, diffuse interstitial fibrosis and sarcoidosis, which give rise to difficulty in the differential diagnosis of farmer's lung.

Differences in the flora of cereal dusts and of mouldy hay are probably responsible for the lower proportion of F.L.H. reactions obtained in patients with farmer's lung due to mouldy vegetable dusts other than mouldy hay. Further investigations of these other dusts are being pursued by the same methods.

\section{SUMMARY}

A.gar-gel precipitin tests were performed on the sera of 327 United Kingdom farmers, who had given a history of exposure to mouldy hay, with extracts of mouldy hay, Thermopolyspora polyspora, Micromonospora vulgaris, Mucor sp., and Aspergillus fumigatus. Positive reactions in the immunoelectrophoretic test to 'farmer's lung hay' (F.L.H.) antigens were obtained in $89 \%$ of 205 subjects regarded as having farmer's lung, and, of these, $87 \%$ were due to the F.L.H. antigens derived from $T$. polyspora. These sera gave reactions to all three of the main F.L.H. antigens (A, B, and C) in $42 \%$ of cases, to two in $31 \%$, and to one in $14 \%$. The wider the range of the serological reaction, the greater was the frequency of reactions to the other extracts, the more frequent and severe were the attacks, the higher the degree of clinical sensitivity to the dust of mouldy hay, and the higher the proportion of males, presumably because they were more heavily exposed. F.L.H. reactions ( $T$. polyspora type) were obtained with the sera of Icelandic patients with farmer's lung. In 16 patients with farmer's lung due to other vegetable dusts only $50 \%$ gave F.L.H. reactions. 
In 122 farmers, who had been exposed to mouldy hay and were not suffering from farmer's lung, F.L.H. reactions were obtained in $18 \%$ of 28 apparently unaffected farmers, in $15 \%$ of 61 with asthma and bronchitis, and in $21 \%$ of 33 with other lung disease, these reactions being much weaker in intensity than in the farmer's lung patients.

In tests on the sera of subjects who had not been exposed to mouldy hay, some having been exposed to other vegetable dusts, no F.L.H. reactions were obtained against extracts of mouldy hay in tests on 304 sera, and no reactions (except in five bagasse workers) were obtained against an extract of $T$. polyspora in tests on 302 sera.

Trichloracetic acid fractionation of $T$. polyspora extract gave a precipitate containing the $\mathrm{A}$ and $\mathrm{B}$ antigens and a supernatant containing the $C$ antigen. Both fractions provoked systemic and pulmonary reactions in affected subjects in inhalation tests.

The mode of onset of the farmer's lung was insidious in $49 \%$ (group I), insidious and later typical in $9 \%$ (group 11), typical in $32 \%$ (group 111 ), and insidious and/or typical and later rapid in $10 \%$ (group IV). The latter group had many of the clinical and serological features of the other groups.

W'e are grateful to the many clinicians who provided material for this investigation; to the Department of
Physiology, Institute of Diseases of the Chest, for the inhalation tests; and to Professor J. G. Scadding for his interest and advice.

\section{REFERENCES}

Bishop, J. M., Melnick, S. C., and Raine, J. L. (1963). Farmer's lung: studies of pulmonary function and aetiology. Quart. $J$. Med., 32, 257.

Campbell, J. Munro (1932). Acute symptoms following work with hay. Brit. med. J., $2,1143$.

Dickie, H. A., and Rankin, J. (1958). Farmer's lung: an acute granulomatous interstitial pneumonitis occurring in agricultural workers. J. Amer. med. Ass., 167, 1069.

- (1960). In Clinical Cardiopulmonary Physiology, ed. B. L. Gordon, 2nd ed., p. 810. Grune and Stratton, New York.

Fuller, C. J. (1953). Farmer's lung; a review of present knowledge. Thorax, 8, 59.

Gregory, P. H. and Lacey, M. E. (1963). Mycological examination of dust from mouldy hay associated with farmer's lung disease. J. gen. Microbiol., 30, 75 .

Jenkins, P. A. (1964). Immunological studies in farmer's lung. Ph.D. thesis presented to University of London.

Kobayashi, M., Stahmann, M. A., Rankin, J., and Dickie, H. A. (1963). Antigens in mouldy hay as the cause of farmer's lung. Proc. Soc. exp. Biol. (N.Y.), 113, 472.

Pepys, J., Riddell, R. W., Citron, K. M., and Clayton, Y. M. (1961). Precipitins against extracts of hay and fungi in the serum of patients with farmer's lung. Acta allerg. $(K b h), 16,76$.

(1962). Precipitins against extracts of hay and moulds in the serum of patients with farmer's lung, aspergillc sis, asthma, and sarcoidosis. Thorax, 17, 366.

- Jenkins, P. A., Festenstein, G. N., Gregory, P. H., I acey, M. E., and Skinner, F. A. (1963). Farmer's lung. Thermophilic actinomycetes as a source of "farmer's lung hay" antigens. Lancet, 2 , 607.

Seal, R. M. E., Thomas, G. O., and Griffiths, J. J. (1963). Farmer's lung. Proc. roy. Soc. Med., 56, 271.

Staines, F. H., and Forman, J. A. S. (1961). A survey of farmer's lung. J. Coll. gen. Practit., 4, 351 .

Studdert, T. C. (1953). Farmer's lung. Brit. med. J., 1, 1305.

Williams, J. V. (1963a). Inhalation and skin tests with extracts of hay and fungi in patients with farmer's lung. Thorax, 18, 182. (1963b). Pulmonary function studies in patients with farmer's lung. Ibid., 18, 255. 